\title{
Can MOOK Fires Bring Light to Shadow Education
}

\author{
Gary Boyd \\ University of the Incarnate Word \\ 4301 Broadway, San Antonio, TX 78209, US A
}

Tel: 1-210-829-3133Ｅ-mail: boydgary@gmail.com

Dr. Noah Kasraie (Correspond ing author)

Dreeben School of Education, University of the Incarnate Word

4301 Broadway, San Antonio, TX 78209, US A

Tel: 1-210-829-3133 E-mail: kasraie@ uiwtx.edu

\author{
Accepted: July 01, 2013 Published: August 17, 2013 \\ Doi:10.5296/ijld.v3i4.4111 URL: http://dx.doi.org/10.5296/ijld.v3i4.4111
}

\begin{abstract}
The New York Times has named 2012 as "The Year of the MOOC." With more than 1.3 million users, the Chronicle of Higher Education writers have called MOOCs the "Campus Tsunami", declaring that "College May Never Be the Same." How did we get here? What have been the drivers that led us to this point in our educational history? Scholars identify at least four drivers that have converged to make the timing ripe for MOOCs. This paper reviews the current literature on the new phenomenon of MOOCs, discusses its relationship on the international scene where shadow tutoring poses more problems than benefits, and recommends future research on areas in which clear gaps exist in the body of the literature.
\end{abstract}

Keywords: MOOK, Higher Education, Shadow Education, Online Education

\section{Introduction}

Like an avid sports fan flipping between PGA golf and March Madness basketball on the television, many educators today are using electronic searches and alerts to flip between MOOCs and Shadow Education. The two academic topics are separate and seemingly unrelated, yet they have come to intersect during times of reflection. With more than 1.3 million students, many believe MOOCS are changing the world of education and engaging the planet (Young, 2013). So are MOOCS the next big thing in higher education in the $21^{\text {st }}$ century or is this all just a hype?

In this paper, we will first briefly look at the well-documented issue of so-called shadow education internationally, with a solution-needing mindset. We will then delve into the new MOOC phenomenon spawned in the United States, mainly among top-tiered universities. For this we shall employ an application-seeking mindset. Finally, we will see where, if at all, these two might intersect and whether there might be possible, positive outcomes from such an overlay. We begin in the shadows. 


\section{Shadow Education}

Jeffery D. Sachs (2005), Paul Collier (2007) and William Easterly (2006) are often combative economists. They differ widely on the causes of global poverty and divide even further on the fixes. They would likely, however, be united in supporting Virginija Budiene's (2006) foreword to Education in a Hidden Marketplace. There she states "that quality public education is essential for building an open, democratic society, for maintaining social cohesion in any country, and for improving the quality of life of citizens and residents." (p. 7).

Countries under development towards democratic, market-based systems have been constantly at work reforming their education systems (Bray, 2009). One of their purposes has been to create an effective, high-quality educational environment for every child. This change to a market-driven economy however, has produced some unpredicted and unwanted consequences. The very educational systems they are seeking to build may be jeopardizing equal access to quality education, and potentially undermining the very fabric of their societies (Bray, 1999).

This happens because operating parallel, but outside institutional systems of education, exists what experts refer to as shadow educational systems of private supplementary tutoring (Bray, 2009). Apparently, these tutoring systems are quite prevalent (Ireson, 2004). This private tutoring is fee-based and market driven typically serving high achievers, and differs substantially from tutoring that comes casually from university students, or is stimulated by government policies to support low achievers.

On the positive side, this shadow tutoring seems to show some benefits. It may be economically good for the tutors, usually underpaid teachers or university students, by supplying them extra income. It helps students gain a competitive edge. It may become a source of motivation for students with low self-confidence (Ireson \& Rushforth, 2005) and it can be a constructive out-of-school activity for unsupervised youth.

Increasingly, however, research indicates this shadow education system is doing more harm than good (UNESCO, 1999; World Bank, 2004; OECD, 2006; ADEA, 2008; UNICEF, 2007). The list of negative effects includes increasing social inequities, undermining mainstream curricula and teacher performance in regular schools, encouraging corruption, skewing the university admissions process, depriving the state of tax revenues, and placing heavy pressure on students and their families (Bray, 2003).

This market-driven tutoring pressure may come from the teachers themselves, peer pressure upon the students, or from the parents who see this as a major path to educational and financial advancement (Bray, 2009).

One substantial research project conducted by the Open Society Institute (2006) of former soviet block countries, now moving towards a market driven economy, revealed all of the negative effects aforementioned that are associated with this shadow tutoring. The study surveyed 8,713 respondents who were mostly first-year university students. As Table 1 illustrates, the respondents reported that they had received private tutoring in the form of lessons or courses during their final year of secondary school. 
Table 1. Percentage of students receiving private tutoring in 2004

\begin{tabular}{lccc}
\hline Country & GDP (\$) Unemployment rate & Percentage of students receiving tutoring \\
\hline Azerbaijan & 957 & 1.4 & $93 \%$ \\
Georgia & 1384 & 42.5 & $80 \%$ \\
Ukraine & 4857 & 22.3 & $79 \%$ \\
Mongolia & 897 & 1.2 & $71 \%$ \\
Poland & 4398 & 11.3 & $66 \%$ \\
Lithuania & 462 & 3.0 & $62 \%$ \\
Bosnia & 4885 & 17.8 & $57 \%$ \\
Slovakia & 4488 & 17.8 & $56 \%$ \\
Croatia & 917 & 3.8 & $56 \%$ \\
\hline
\end{tabular}

The survey also indicated that the four participating countries with the largest scope of private tutoring (Azerbaijan, Georgia, Mongolia, and Ukraine) also have the lowest per capita Grass National Income. Nearly 60 percent of respondents in Azerbaijan and over 50 percent in Georgia indicated that private tutoring is the only way to get high quality education.

Most respondents in Azerbaijan (66.5 percent), Mongolia (63.7 percent), and Ukraine (58.7 percent) indicated that they believed that teachers treat students who take private tutoring better than they treat student who do not.

In some of the participating countries, respondents reported that some teachers pressured their students to take supplementary private tutoring with them after school hours. In some cases, this included threatening students with lower grades if they refused to take private tutoring. The same study records that one secondary school teacher in Sarajevo, Bosnia and Herzegovina said:

Everybody knows about it and no one is doing anything about it. Our teacher offer tutoring in the worst possible way...(They say,) "If I teach math in this school and am not allowed to tutor my own students, then I will tutor students from other schools. I will tell them who they should hire as tutors and I will know who will send students to me in return..." it is a smoothly run affair (p. 14).

The study also revealed that some university lecturers and professors who are familiar with the content of entrance examinations act as monopoly suppliers of tutoring services to potential university students.

What if there was another way; another method of gaining a quality supplemental education, without the fraud, corruption, pressure and expense? What if the current crop of American MOOCs could fill the gap? Especially if they were to partner with American universities equipped to conduct MOOCs. What if MOOCs could at least fill part of the needs that shadow education is attempting to fill?

Let us now look at these MOOCs in more detail, beginning with a MOOC story.

\section{MOOCs}

Imagine being an intelligent 15-year-old boy, passionate about science and math, and living in Mongolia. You realize that the world's leading experts in your field of interest in Artificial Intelligence (AI) are 8,619 miles away, located on the campus of Stanford in the United States. You know that you have no access to travel, no access to entrance in that university, and no money to attend even if you could. Then imagine hearing the startling news that the two experts from Google's headquarters, some four miles from Stanford, are going to teach such a course. Further, Stanford will offer that online course free of charge, and with no admission requirements. Open for anyone to enroll online, regardless of background, class, financial 
status, race, gender or global location. How excited would you be? How might this affect you? How much could you learn? How might this affect the future of Artificial Intelligence? This scenario was real, the boy was real, the instructors Sebastian Thrun and Peter Norvig were real and the course was real. Approximately 160,000 people from around the globe signed up for this first ever course in this new genre.

Some have called 2012 the year of disruptive education (ACM, 2012). The front page of the New York Times Educational section further specified 2012 as, "The Year of the MOOC" (2012, November 4). The recently released College and University Libraries Proceedings report headlines the question, "Are You MOOC-ing Yet?" (2013, January). The Chronicle of Higher Education writers have called MOOCs the "Campus Tsunami", declaring that "College May Never Be the Same" (Synder, 2012). Hardly a day in the news of higher education goes by now without some reference to MOOCs.

\subsection{Definition}

So, what is a MOOC and how did it come to occupy such a spotlighted space? Again, MOOC stands for Massive Open Online Course and was a term first used by Dave Cormier of the University of Prince Edward Island in 2008 (Mehafy, 2012). Cormier used the term to describe an open course created by George Siemens and Steven Downes offered to 25 students at the University of Manitoba. Breaking down the acronym we see it represents:

- Massive - think thousands of participants signing up for a single course.

- Open - open to anyone; no prerequisites, no cost, no geographical boundaries.

- Online - the entire course is online, with only an Internet connection and a simple online sign- up process required.

- Course - a single, newly designed course specially created for these online students. MOOCs are large-scale online courses where an expert or group of experts facilitate a series of interactive lectures and discussion in an open access format via the web (Atkisson, 2011). MOOCs are an online phenomenon, which has gathered great momentum over the past five years. MOOCs combine the connectivity of social networking with the power of a great class, led by a leading subject matter expert. Importantly however, MOOCs also build on the active engagement and interaction of the thousands of participants who self-organize around their prior knowledge skills, their own class goals, or other common interests. These collaborative connections form a strong basis for positive student outcomes. However, along with no fees, no prerequisites and no prequalification, MOOCs also carry no formal accreditation (McAuley, Stewart, Siemens, \& Cormier, 2010).

\subsection{History}

In late 2011 and early 2012, many top U.S. universities like MIT, Stanford, Princeton, Harvard, University of Michigan and the University of Pennsylvania have placed some of their classrooms online. Since then, a host of other colleges has joined the frenzy (Tschofen \& Mackness, 2012). This has opened the door for students the world over to have unprecedented access to courses never before within their grasp. One course in particular may have been the tipping point that launched the pent-up MOOC movement. It was the course alluded to in the opening, called "Introduction to Artificial Intelligence" taught by Peter Norvig, Google's director of research, and Sebastian Thrun, a Google vice president at the time. The course offered in the fall of 2012 signed up more than 160,000 participants, with 23,000 completing the course (Leckhart, 2012). "This has caught all of us by surprise," says David Stavens of Coursera. One student enrolled in this AI class wrote for Wired Magazine,

People around the world have gone crazy for this opportunity. Fully two-thirds of my 160,000 class mates live outside the US. There are students in 190 countries - from India and South Korea to New Zealand and the 
Republic of Azerbaijan. More than 100 volunteers have signed up to translate the lectures into 44 languages, including Bengali. In Iran, where YouTube is blocked, one student cloned the CS221 class website and-with the professors' permission—began reposting the video files for 1,000 students.

Aside from computer-programming AI-heads, my classmates range from junior-high school students and humanities majors to middle-aged middle school science teachers and seventy something retirees. One student described CS221 as the "online Woodstock of the digital era (Leclhart, 2012)."

\subsection{MOOC Providers}

Stavens, along with Michael Sokolsky and Sebastian Thrun, went on to co-found a new course provider company called Udacity, (University and Audacity) one of three such providers along with edX and Coursera. They saw an opportunity to both capitalize on the MOOC movement as well as enter the ground floor as established thought leaders forming methods to deliver such courses. Udacity contracts directly with professors and offers MOOC courses mainly related to math and computer science. Acceptance has spread so fast, that in September 2012, Colorado State University's global campus announced that it would for the first time, accept transfer credits from student who passed Udacity's proctored exam. A powerful, and to many, a stunning announcement (The Chronicle of Higher Education, 2012).

Other universities have joined the rush to MOOCs. In May 2012, Harvard University joined MIT in an extension of MIT's OpenCourseW are project, called $e d X$ (Parry, 2012). The offices are barely arranged and the organizational charts hardly printed, yet this nonprofit start- up $e d X$, had an enrollment of 370,000 for the Fall 2013 semester and its first official course offering. As impressive as that may be, Coursera founded as a for profit MOOC course provider just last January 2012, has already enrolled more than 1.7 million. Coursera's chief Andrew Ng proudly says it is growing "faster than Facebook" (2012). Again, America's so-called "elite" universities are signing onto the concept rapidly. Brown, Columbia, Duke, and Princeton are now on board with Coursera. Additionally, Stanford University announced its own Class2 Go courses. Last September Google, never too late to the party, released its new online MOOC development tool called Course Builder, designed to allow anyone to create online education MOOC courses (Daniel, 2012). It is open source software, and it is free.

\subsection{MOOC Drivers}

How did we get here? Why MOOCs now? What have been the drivers that led us to this point in our educational history? Scholars identify at least four drivers that have converged to make the timing ripe for MOOCs. These four are: technology, demography, pedagogy, and economy (Ostrander, 2012; Wood, 2013). These four are visible when one studies globalization. These four international ingredients have been undergoing rapid changes over the last decade, if not the last fifty years. Each of these individual ind ustries and disciplines has converged at this point in history to form a new confluent stream.

\section{Discussion}

This new stream has the potential to alter, some say "revolutionize" (Friedman, 2013) higher education as we now experience it. Nevertheless, MOOCs as we currently experience them, pose many important questions for academia, especially in the United States. Questions, for which there are no easy ans wers.

But, what about the effects on the international scene where shadow tutoring poses more of a problem? Let us do a simple comparison in Table 2. 
Table 2. Comparison of shadow education and MOOCs

\begin{tabular}{|c|c|}
\hline Shadow Education & MOOCs \\
\hline Costly to end-users & Free to end-users \\
\hline Subject content in clas srooms & Subject content anywhere, anytime \\
\hline $\begin{array}{l}\text { Taught by same teachers: } \\
\text { Underpaid } \\
\text { May be bad teachers } \\
\text { May have no subject matter expertise } \\
\text { May have vested interest in profit from } \\
\text { students } \\
\text { May be locally corrupt } \\
\text { May have personal bias against the student }\end{array}$ & $\begin{array}{l}\text { Taught by different teachers: } \\
\text { Adequately paid } \\
\text { Excellent teachers } \\
\text { World renowned experts } \\
\text { No vested interest in profiting from students } \\
\text { Without local corruption } \\
\text { No personal bias towards student }\end{array}$ \\
\hline May require travel & Requires no travel \\
\hline May require assistance to attend & Requires no assistance to attend \\
\hline May create social inequalities & Equal access creates not inequality \\
\hline $\begin{array}{l}\text { Consumes human \& financial resources of the } \\
\text { end users, beyond the student energies }\end{array}$ & $\begin{array}{l}\text { Beyond the student energies, no other } \\
\text { end-user resources are required }\end{array}$ \\
\hline May distort the mainstream curriculum & Should support the mainstream curriculum \\
\hline May upset sequential content planning & Should support the content planning \\
\hline May exacerbate diversity in classrooms & Potentially creates less diversity in classrooms \\
\hline Proves to be ne gative & Proves to be positive \\
\hline
\end{tabular}

There are MOOC initiatives happening all over the globe. In Germany, a Berlin group has created iversity and now is offering 25k Euros to the winner of a MOOC development contest. In February 2013, Switzerland's Ecole Polytechnique Federale de Lausanne joined the Harvard/MIT platform edX to de velop and offer MOOCs. MIT Review reports this same edX group is also partnering with groups in East and Central Africa to offer a civil engineering course designed especially for Francophone regions (MIT Technology Review, 2013, March 15). In Rwanda, a nonprofit called Generation Rwanda is starting a bold experiment: an entirely MOOC-based university. MIT Technology Review (2013, Nov 12) also reports this amazing story:

When prominent U.S. universities began offering free college classes over the Web this year, more than half of the students who signed up were from outside the United States. Consider the story of one of them: Carlos Martinez, a professor of electrical engineering at the University of El Salvador. Last spring, Martinez enrolled in a class on electronic circuits offered by edX, the $\$ 60$ million collaboration between MIT and Harvard to stream "massive open online courses," or MOOCs, over the Web. He thought it was so good that he began traveling around El Salvador to convince others to join the class and launched a blog in English to document his adventures as his country's first "MOOC advocate."

Sal Khan's Academy online, now gets some 6.5 million unique hits per month. The era of MOOCs is upon us. 


\section{Conclusion and Recomme ndations}

Future quantitative and qualitative studies are recommended to investigate the academic potential and measurable learning benefits of MOOCs. Examining the challenges of receiving college credit for taking MOOC classes is another area for future research. Evaluating the experiences of students and their satisfaction level in MOOC classes also could be surveyed. Investigating the relationship between digital literacy and learning in MOOC classes is another topic that could be researched. Finally, future studies are recommended to investigate the effects of MOOCs on shadow education.

It is our belief that MOOCs hold promise for potentially alleviating some of the shadow education problems around the Globe. After all, one of the biggest issues MOOCs have to answer in America is whether "college credit" will ever be allowed for these courses. In a Mongolian high school setting, where supplemental education is the key, credentialing is not the issue. Here the fixed courses of Khan Academy, or the Internet (or downloadable) courses of edX, Udacity or Coursera may fill the need beautifully. Assuming the technology is there, mainly sustainable Internet connectivity, the MOOC wildfires may shed light on this shadowy problem.

\section{References}

Atkisson, M. (2011, August, 28). Comparing MOOC's, MIT's Opencourseware, and Stanford's massive AI course[Web log post]. Retrieved from: http://woknowing.wordpress.com/2011/08/28/comparing-moocs-mits-opencourseware-a nd-stanfords-massive-ai-course/

Aurini, J. \& Davis, S. (2004). The transformation of private tutoring: Education in a franchise form. The Canadian Journal of Sociology, 29(3), pp. 419-438.

Baker, D.P. \& LeTendre, G.K. (2005). National Differences, Global Similarities: World Culture and the Future of Schooling. Stanford: Stanford University Press.

Bray, M. (1999). The Shadow Education System: Private Tutoring and its Implications for Planners. Paris: UNESCO International Institute for Educational Planning.

Bray, M. (2003). Adverse Effects of Private Tutoring: Dimensions, Implications, and Government Responses. Series: Ethics and Corruption in Education. Paris: UNESCO International Institute for Educational Planning.

Bray, M. (2005a). Private Supplementary Tutoring: Comparative Perspectives on Patterns and Implications. Paper presented at the Oxford International Conference on Education and Development,13-15 September.

Bray, M. \& Bunly, S. (2005). Balancing the Books: Household Financing of Basic Education in Cambodia. Hong Kong: Comparative Education Research Centre, The University of Hong Kong, and Washington D.C.: Human Development Unit, East Asia and Pacific Region, The World Bank.

Bray, M. \& Kwok, P. (2003). Demand for Private Supplementary Tutoring: Conceptual Considerations, and Socio-Economic Patterns in Hong Kong. Economics of Education Review, Vol. 22,No. 6, pp. 611-620. 
Collier, P. (2007). The Bottom Billion: Why the poorest countries are failing and what can be done about it. Oxford University Press: New York.

Cormier, D., \& Siemens, G. (2010). Through the Open Door: Open Courses as Research, Learning, and Engagement. Educause Review, 45(4), 30-39.

Daniel, J. (2012). Making sense of MOOCs. Academic Partnership website: http://www.academicpartnerships.com/docs/default-document-library/moocs.pdf

De Silva, W.A. (1994). Extra-school Tutoring in the Asian Context with Special Reference to Sri Lanka. Maharagama: Department of Educational Research, National Institute of Education.

Easterly, W. (2006). The White Man's Burden: Why the west's efforts to aid the rest have done so much ill and so little good. The Penguin Press: New York.

Ireson, J. (2004). Private tutoring: How prevalent and effective is it? London Review of Education, 2 (2), pp. 109-122.

Ireson, J., \& Rushforth, K. (2005). Mapping and evaluating shadow education. Retrieved from Economic and Social Research Council website: http://www.esrc.ac.uk/my-esrc/grants/RES-000-23-0117/read http://image.guard ian.co.uk/sys- files/Education/documents/2005/04/07/tutoring.pdf

Kim, J. (2012). Playing the Role of MOOC Skeptic: 7 concerns. Inside Higher EdTechnology and Learning, Retrieved http://www.insidehighered.com/blogs/techno(logy-and- learning/playing-rolemooc-skeptic-7-concerns

Leckhart, S. (2012). The Stanford Education Experiment Could Change Higher Learning Forever. Wired website: http://www.wired.com/wiredscience/2012/03/ff_aiclass/3/

Maslen, G. (2013). MOOCs Spread Around The edX and Coursera World. ). University World News, February 21, 2013 Issue No:260. Retrieved from: http://www.universityworldnews.com/article.php?story=2013022110195197

Morrison, D. (2012). Online learning insights [Web log post]. Retrieved from: http://onlinelearninginsights.wordpress.com/2012/05/29/mooc-mythbusterwhat-moocs-are-and-what-they-arent/

MIT Technology Review. (2013, March, 15). In the developing world, MOOCs start to get real. http://www.technologyreview.com/news/512256/in-the-developing-world-moocs-start-to -get-real/

OECD. (2006). Demand-sensitive schooling: evidence and issues. Paris: Organization for Economic Co-operation and Development.

Open Society Institute (2008). Open Society Education Monitoring Initiative. Retrieved from: www.soros.org/initiatives/esp/focus_areas/emi 
Open Society Institute, (2006). Education in a Hidden Marketplace: Monitoring of private tutoring. http://www.opensocietyfoundations.org/reports/education-hidden-marketplace-monitorin g-private-tutoring

Parry, M. (2012). Five ways the Edx could change education. The Chronicle of Higher Education http://chronicle.com/article/5-Ways-That-edX-Could-Change/134672/

website:

Sachs, J. D. (2005). The End of Poverty: Economic possibilities for our time. Penguin Books: New York.

The Economist Intelligence Unit (EIU, 2012). Retrieved from: http://www.economist.com/topics/economist-intelligence-unit

World Bank. (2004). Vietnam: reading and mathematics assessment study. Vol. 2.

Washington DC: Human Development Sector Unit, East Asia and Pacific Region, World Bank.

World Bank. (2005). Expanding opportunities and building competencies for young people: a new agenda for secondary education. Washington DC: World Bank.

Young, J. (2012). From Self-Flying Helicopters to Classrooms of the Future. Retrieved from: http://chronicle.com/article/Massive-Excitement-About/134666/ 